\title{
IMPACT OF IMPROVED ANIMAL FEEDING PRACTICE ON MILK PRODUCTION, CONSUMPTION AND ANIMAL MARKET PARTICIPATION IN TIGRAI, ETHIOPIA
}

\author{
MUUZ HADUSH
}

\begin{abstract}
In this paper, efforts were made to assess the impact of full and seasonal stall feeding technology on households' milk production and consumption, market participation (animal and animal product sale) in Northern Ethiopia using data obtained from the survey of 518 rural farmers. The overall result indicated that SF adoption ensures significant gains in terms of the specified outcome indicators. Using endogenous switching regression models, we estimate different outcome indicators for both adopters from adoption (ATT), and non-adopters had they adopted (ATU).

It is identified that there would be a decline of $21 \%$ in milk production and productivity if adopters did not adopt this technology while non-adopters are estimated to increase their milk production and productivity by $100 \%$ and $48 \%$, respectively, if they adopted this technology. The results further show that SF adoption had a significant increment in lactation period. An increase of consumption expenditure by $17 \%$ from FSF and 44\% in the case of SSF could be considered significant on livelihoods for smallholder farmers. The adoption of SF increased the likelihood of participating in an animal sale market by $29 \%$ for adopters and by $47 \%$ for non-adopters had they decided to adopt.
\end{abstract}

Keywords: household welfare, input use, animal market participation, land investment, endogenous switching regression, Ethiopia.

JEL codes: Q01, Q18, Q57.

Muuz Hadush PhD student at Norwegian University of Life Science (NMBU);

Ås, Norway \&Lecturer at Mekelle University, Department of Economics Email: muuz.hadush@mu.edu.et; Phone: (251)-914732232 and P.O.Box:451, Mekelle-Ethiopia. 


\section{Introduction}

Agriculture is an important motor for realizing economic development in subSaharan Africa (SSA), where agriculture accounts for about $43 \%$ of the gross domestic product and over $60 \%$ of exports. Nearly about $90 \%$ of the poor depend on agricultural productivity to lift them out of poverty (Odame et al., 2013). However, unlike other regions of the world, the region has continued to experience low agricultural productivity with its share at $3.9 \%$ to world food production in the last decade (Odame et al., 2013). A large proportion of the rural households in developing countries own livestock, which is valuable financially and plays significant social and economic roles on rural farms (World Bank, 2008; Herrero et al., 2013). Livestock contributes to the livelihoods of at least $70 \%$ of Eastern Africa's rural farmers in terms of income and diet (Cecchi et al., 2010).

In Ethiopia, dairy sector plays an important role in the agricultural sector (Tegegne et al., 2013). Livestock contributes about 12-16\% of the total GDP, and $40 \%$ of the total agricultural GDP excluding the values of draught power, transport and manure, and it contributes to the livelihoods of about $60-70 \%$ of the population (Halderman, 2004). Milk and milk products play a very important role in the feeding of the rural and urban people. It also provides 14 million tons of manure annually mainly used for fuel. The value of an animal draught power input into arable production is about a quarter of the value of annual crop production (Behnke and Metaferia, 2011; FAO, 2005). However, the performance of livestock sector has been poor compared to the other parts of the world due to inadequate feed nutrition and poor feeding practices, shrinking area of natural pastures, animal infections and weather fluctuations (Odame et al., 2013; FAO, 2009; IFAD, 2007) next to the predominance of local, low-yielding breeds, the inadequate availability of water resources for drinking and the high rates of livestock mortality (Negassa and Jabbar, 2008).

In spite of its huge potential, production per animal is extremely low in Ethiopia (MoA, 2012; CSA, 2008). Milk production is 1.54 litres per cow per day. The current per capita consumption of milk and meat is 16 litres and $13.9 \mathrm{~kg} / \mathrm{year}$, respectively; being lower than the African and the world per capita consumption of meat, which is $27 \mathrm{~kg} /$ year and $100 \mathrm{~kg} /$ year, respectively (FAO, 2009). As a result, Ethiopia is classified as having the lowest per capita consumption of meat and milk, even among neighbouring countries like Kenya. Land degradation, resulting from free grazing and deforestation, reduces the contribution from livestock and poses a threat to food security in the region (Ilyin, 2011). Recognizing this, improved agricultural technologies are widely considered as the key means of addressing most of the problems of low livestock productivity throughout the region (Diao and Pratt, 2007). The expansion of improved cattle feeding has been suggested by policymakers with the objectives of (1) increasing cattle and fodder productivity; (2) halting land degradation, and (3) generating income (Lenaerts, 2013).

For instance, stall feeding (SF) or zero grazing (ZG) have been widely recommended and practiced across sub-Saharan Africa, while its pace of intensification 
was slower than anticipated (De Cao, van den Berg, Tile and Wondwosen, 2013; Bishu, 2014; Lenaerts, 2013). The practices of stall feeding along with the breed cows is being promoted in Ethiopia at different phases as potential options for alleviating animal feed shortage problems and increasing livestock productivity (Benin, Ehui and Pender, 2006; Klitzing et al., 2014; Lenaerts, 2013; De Cao et al., 2013; Bishu, 2014). The introduction of stall feeding as the system under which cattle are permanently kept in the backyard and feed fodder crops, crop residues via 'cut-and-carry system' entails the establishment of garden pastures, demarcation of the homestead for herding, breeding and fodder trees under intensive feed gardens for forage production.

Earlier studies in the region, using descriptive statistics, indicated that SF/ZG has several benefits over extensive grazing systems: SF offers a regular income throughout the year as compared to cash crops (Klitzing et al., 2014). It is also linked to a better utilization of fodder, increased milk output, better manure management, intensive land use, and low risk of infection by tick-borne diseases, and protection of animals against theft (Bishu, 2014). Besides, Garcia, Balikowa, Kiconco Ndambi and Hemme (2008), using a qualitative method, found that SF in Uganda was economically and ecologically sustainable. Baltenweck, Tenywa and Mugisha (2007) in Tanzania and Staal et al. (2003) in Kenya, using simple budget analysis method, estimated that ZG was more profitable. De Cao et al. (2013) revealed that ZG is a potentially useful practice against low productivity and limited feed availability in Ethiopia. Although SF stall feeding is believed to be profitable, its pace of coverage has been recorded to be slow and low in the region (FAO, 2007; Nedessa, Ali and Nyborg, 2005; Lenaerts, 2013; Bishu, 2014), particularly in Ethiopia.

One possible reason for the relatively slow adoption of the new practice has been probably due to the relative advantage it offers (Ghadim et al., 2005). Based on Cary, Webb and Barr (2001) expected profits are a decisive factor in adoption decisions. Ghadim et al. (2005) revealed that the short-term profitability of new legume crops significantly influenced their adoption. D'Emden, Llewellyn and Burton (2006) found that the adoption of conservation tillage in Australia was influenced by its cost. The economic and ecological benefits of SF are neither properly documented nor properly evaluated. The objective of this paper was, therefore, to jointly estimate adoption of SF and evaluate its impact on rural household's welfare ${ }^{1}$ in rural Ethiopia adapting Endogenous Regression Model (ERM) (Lokshin and Sajaia, 2004). The paper intends to address the following research question: What is the economic impact of SF?, To what extent adopters would be worse off if they were non-adopters? and How much would the non-adopters benefit had they been adopters?

The uses of ERM allow us to hypothesize that participants would be worse off than non-participants, if they decided not to adopt and non-participants would benefit more than participants if they were to participate. That is, we anticipate

\footnotetext{
${ }^{1}$ In terms of milk production and consumption expenditure, lactation, and live animal and animal product sale market participation.
} 
that the predicted impact for adopters will decline from real adoption to hypothetical adoption, but will increase from real non-adoption to hypothetical adoption for non-adopters. In line with this expectation, our result showed that there would be a decline in animal sale, milk production and consumption had adopters been non-adopters. In the same fashion, animal sale, milk production and consumption would increase if non-adopters would adopt this technology.

This paper distinguishes itself from past related studies in three ways. Firstly, we are perhaps the first to show how stall feeding users compared to non-users benefit from it, using proper evaluation design compared to prior survey studies which totally neglected the selectivity effects and endogeneity problem. Secondly, our approach provides not only a joint estimation of adoption and its impact, but also estimates of conditional and unconditional expectation. Thirdly, stall feeding is a new practice in the country, whose adoption is slow, probably due to a lack of understanding of its positive impact. Being able to precisely estimate its impact, would influence the possible types of policies to be implemented in order to expand its coverage.

\section{Literature Review}

Livestock is a primary livelihood source for many low-income rural farmers particularly in sub-Saharan Africa (Grassi et al., 2015). In line with this, Yilma, Guernebleich, Sebsibe and Fombad (2011) indicated that livestock production in Ethiopia contributes up to $80 \%$ of farmers' income, about 20 percent of agricultural GDP, full-year employment and $16 \%$ share in export. In spite of large cattle population, the contribution of livestock production to agriculture is below the expected level and dropping (Gebremedhin, Hirpa and Berhe, 2004; Ilyin, 2011). The average daily milk production was only 1.69 litres with average lactation length of about 180 days and mean annual milk yield per cow of 305 litres. The per capita milk consumption has decreased from 26 litres per annum in 1980 to 22 litres in 1993, 19 litres in 2000 and 16 litres in 2009 (Yilma et al., 2011). A study conducted by Klitzing et al. (2014) in the highlands of Ethiopia showed that the performance of the sector is challenged primarily by a low quality and quantity of feed resources and seasonal fluctuations in feed resources.

Similarly to many other environmentally vulnerable countries, Ethiopia has faced rampant land degradation in the form of an immense gully and soil erosion caused by overgrazing and deforestation (Teshome, Graaff, Ritsema and Kassie, 2016; Gessesse, Bewket and Bräuning, 2016). In response to extensive degradation of the resource base, different land management measures have been introduced in the country, such as stone terraces, soil bunds and agroforestry practices on cultivated fields, as well as area closure (Frankl et al., 2016). Ewnetu and Bliss (2010) and Teshome et al. (2016), mentioned that among other things, demographic characteristics, farming practices, agro-ecological conditions, access to roads and markets, and land-use policies, property rights and level of extension services are some of the critical factors affecting management investment decisions in Ethiopia. In view of this, the extent of determinants of tree-planting decisions as a land management strategy is examined in this section. 
Throughout sub-Saharan Africa, the introduction of improved feeding has been seen by policymakers as key objectives of (1) increasing livestock productivity; (2) curbing land scarcity and land degradation, and (3) generating income. In line with this, stall feeding (Zero Grazing), rotational grazing and tethering where animals are fed dry hay, straw, cactus and other extra nutritional fodders under a sheltered woody tent or tree shelter were widely recommended across the region and practiced in the highlands of Kenya and Tanzania as well as in Ethiopia (Lenaerts, 2013; Klitzing et al., 2014; Bishu, 2014; Gebremedhin et al., 2009), although its expansion was slower than anticipated. Sserunkuuma (2005) in his study on the adoption of land management technologies in Uganda found that low level of adoption of improved technology is associated with low profitability. Farmers tend to use only technologies that they consider profitable, despite all other non-monetary factors that could deter technology adoption decision (Kabirizi, 2006).

The practice of SF in Uganda was found to be economically and ecologically sustainable (Garcia et al., 2008). Zero grazing in Tanzania was more economically and environmentally viable where breed cows under this practice produce 1,500 liters of milk per lactation in 1.5 years at a cost of 1,000 hours annually for collecting fodder and water (Hotland, 2007), but Meul, van Passel, Fremaut and Haesaert (2012) in Australia found that zero grazing performed significantly worse from an ecological and economic point of view. A recent study by Klitzing et al. (2014) in Ethiopia revealed that fodder productivity from SF schemes is higher than from free grazing (FG) schemes, leading to overall livestock productivity and higher welfare gain. A survey study conducted by Nyssen, Descheemaeker, Nigussie Haregeweyn, Deckers and Poesen (2007) in the Tigrai also shows that modern grazing practices had ecological and economic benefits.

Nalunkuuma, Affognon, Kingori, Salifu and Njonge (2013) indicated that adoption of ZG had a positive impact on cow breeds owned by farmers in Kenya. De Cao et al. (2013) revealed that ZG was a useful practice to improve cattle productivity and feed availability by reducing free grazing months in Ethiopia. Another result confirmed that almost $80 \%$ of the farmers that adopted improved breeds also adopted stall feeding (Benin, 2006). The finding from Turinawe, Mugisha and Kabirizibi (2011) revealed that farmers using improved forage technology had significantly higher gross profit and a number of breed cows than those using local feeding methods in Uganda. Results from Wambugu, Kirimi and Opiyo (2011) indicated that, on average, the value of milk in the ZG system was Ksh 6,091, compared to Ksh 5,189 in FG systems. Lactation length under $\mathrm{SF}$ is 450 days versus 200 days for free grazing. Pre-weaning calf mortality is about $10 \%$ per annum in ZG compared to $25 \%$ in FG. However, about 730 hours of labour per cow per year is required for SF compared to 330 hours for FG and households practicing ZG incurred higher monthly variable costs per lactating cow (Ksh 5,156) compared to Ksh 3,622 for non-ZG.

An empirical study of Muuz (2017) in Tigrai showed that grazing land, enclosure area, labour, herd and farm size, animal shock, cow breed, access to information and early exposure are found to be the key factors of SF adoption. SF is 
also supposed to minimize risks mainly associated with cattle contact and disease prevalence in FG (Bishu, 2014). While agronomic benefits of this practice are well documented, economic benefits in the study region remained unexplored, though (Gebreyohannes and Hailemariam, 2011), which calls for this study.

\section{Theoretical Model}

In most cases, smallholder farmers make an important decision when they choose to participate in a new intervention. In order to estimate the effect of stall feeding on milk production and consumption, and on market participation, the farm household model, under which the household can maximize utility subject to income, production, and time constraints (Singh, Squire and Strauss, 1986), was adopted as a framework. The choice of this model is based on its merit of integrating the production, consumption and work decision-making processes of the farm household in a single framework. This paper mainly draws from Fernandez-Cornejo, Hendricks and Mishra (2005), who expanded the model of Huffman (1991) to include technology adoption decisions. In this case, the paper focus on farmers' stall feeding practice.

Farm households are assumed to derive utility $(U)$ from purchased consumption goods $(G)$ and a vector of members' leisure and non-economic activities at home $(L)$, and the level of utility obtained from $G$ and $L$ is influenced by exogenous factors, such as human capital $(K)$ and other household characteristics $(C)$. Consulting the work of Fernandez-Cornejo et al. (2005), the utility is denoted by:

$$
\operatorname{Max} U=U(G, L ; K, C)
$$

Where $U$ is assumed to have the usual regularity properties of a utility function, such astwice differentiability, quasi-concavity, and an increase in $G, L ; K, C$. The objective of the farm household is to maximize utility from the consumption of goods and leisure, subject to the farm production, income, and time constraints:

Time constraint :

$$
\begin{array}{ll}
\text { Time constraint : } & T=\mathrm{F}(S F)+M+L, M \geq 0 \\
\text { Production Constraint: } & Q=Q[X(S F), \mathrm{F}(S F), K, S F, R], S F \geq 0
\end{array}
$$$$
\text { Income constraint: } \quad P_{g} \mathrm{G}=P_{q} Q-W_{x} X^{\prime}+W M^{\prime}+A
$$

The production technology (3) is assumed to have all the regularity conditions, such as twice differentiable, increasing in inputs, etc. The total household's time endowment $(T)$ is devoted to leisure $(L)$, working on the farm $(F)$, and off-farm work $(M)$, while the farm output level $(Q)$ depends on the quantity of farm inputs $(X)$ such as land, capital, cow breed, feed, etc. and the practice of new feeding $(S F)$, where $S F$ is considered to be production augmenting, labour and feed-saving technology adoption decision, resulting in some free time and money for other activities, $F, K$, and a vector of exogenous variables that shifts the production function, $(R)$. The adoption of labour-saving technology $S F$ reduces the labour requirement 
on cattle farm production. Thus, its adoption should be incorporated into the production technology implicitly, not as a shifter of the production function. The adoption of $S F$ is further affected by households' animal shock exposure $(S)$, private social capital $(N)$, household assets $(E), K$ and $C$. Thus:

$S F=(\mathrm{S}, \mathrm{N}, \mathrm{E}, \mathrm{K}, \mathrm{C}, \mathrm{R})$

Equation (4) displays the budget constraint on household income where $P_{g} G$ is the income available for purchase of consumer goods at a price $P_{g}$, and it depends on the output price $\left(P_{q}\right)$ and quantity $(Q)$ of farm output, vector input prices $\left(W_{x}\right)$ of quantity $(X)$ of farm inputs, off-farm wages $(W)$ and the amount of time spent working off-farm $(M)$ as well as exogenous household income such as private assistance and safety net support $(A)$. Substituting Equation 3 with Equation 4 produces a farm technology-constrained measure of household income:

$P_{g} \mathrm{G}=P_{q} Q[X(S F), \mathrm{F}(S F), K, S F, R]-W_{x} X(S F)+W M^{\prime}+A$

Maximizing Lagrangian expression $(\mathcal{L})$ over $(\mathrm{G}, \mathrm{L})$ but minimizing it over $(\lambda, \eta)$ yields the Kuhn-Tucker first order conditions:

$\mathcal{L}=U(G, L ; K, C)+\lambda\left\{P_{q} Q[X(S F), \mathrm{F}(S F), K, S F, R]-W_{x} X(S F)+W M^{\prime}+A-P_{g} \mathrm{G}\right\}$ $+\eta[T-\mathrm{F}(S F)-M-L]$

Where: $\lambda$ and $\eta$ represent the Lagrange multipliers for the marginal utility of income and time, respectively. Based on the Kuhn-Tucker condition solution (Fernandez-Cornejo et al., 2005), when solving the model, we could find the following input demand functions

$X^{*}=\left(W_{x}, P_{q}, S F, W, \mathrm{~K}, \mathrm{C}, \mathrm{T}\right)$

Thus, the reduced-form expression of the optimal level of household milk income $\left(\mathrm{Y}^{*}\right)$ can be obtained by substituting the optimal input demand functions into the technology constraint (3) as follows:

$$
\mathrm{Y}^{*}=\left(W_{x}, P_{q}, S F, W, \mathrm{~K}, \mathrm{C}, \mathrm{R}, \mathrm{T}\right)
$$

Likewise, a household demand for consumption goods $(G)$ can be expressed as:

$$
G=\left(S F, P_{g}, P_{q}, \mathrm{Y}^{*}, A, \mathrm{~K}, \mathrm{C}, \mathrm{T}\right)
$$

Hence, the reduced forms of $\mathrm{Y}^{*}$ and $G$ are affected by a set of explanatory variables, including where this paper is mainly intended to estimate the effect of $S F$, on household milk income, household consumption of milk and milk products, and animal market participation. 


\section{Description of the study area and data}

The study was conducted in Tigrai region, in the northern part of Ethiopia, by randomly selecting 632 sample households. This study used a cross-sectional data from Tigrai Rural Household Survey (TRHS) dataset collected in 2015. The TRHS includes a panel of five rounds conducted in 1997/98, 2000/01, 2002/03, 2005/06 and 2014/2015, where the author was involved only in the last round. The available panel dataset provides comprehensive household and plot level data. The primary data used in this paper is adapted from the last, 2014/2015, household survey. Table 1 presents the basic socio-economic characteristics of 518 livestock ownerfarmers drawn from a total of 632 sample farmers.

The outcome variables in this paper include households' milk production; animal product (milk, butter, cheese, yogurt, and dung) consumption, animal sale market participation, lactation length during the survey production year. Adopters are classified as farmers that feed at least one cattle in the full-year (FSF) or in at least singleseason (SSF) during the survey period, while non-adopters are farmers that follow traditional free grazing. The results showed that the percentage of full-adopters and non-users in the full-year round is reported to be $187(36.10 \%)$ and $331(63.9 \%)$, respectively. However, farmers practicing SF at least in one season total to 288 $(55.6 \%)$, whereas those of non-users to $230(44.4 \%)$ in the study area. Table 1 reports summary statistics for the selected outcome indicators and key household characteristics. Adopters of SF are seemingly better off than non-adopters in many aspects.

The average milk yield of a dairy cow in the study area is estimated at 1.69 for adopters and 1.46 litres per cow per day for non-adopters, which is much lower than in neighbouring Kenya (Wambugu et al., 2011). Moreover, adopters are more likely to be involved in animal and animal product markets than non-adopters, with adopters having 54\% share in the market compared to non-adopters that have 51\%. Adopters have a significantly higher annual milk and meat consumption expenditure and longer lactation period. These all indicators point to the fact that adopters are more likely to enjoy benefits than non-adopters. The same statistical analysis result shows that adopting farmers have smaller herd size than non-adopters but have a higher number of milking cows.

As expected, shock exposure for adopters is relatively higher ranging from $16 \%$ for non-adopters and 28\% for adopters. Adopters of SF had a higher number of family members and plots, better access to a mobile phone, and resided closer to the nearest road than non-adopters. Adopters of SF were mainly male headed farms that had greater access to formal credit and resided further away from the free grazing area than non-adopters. Yet another, comparison shows that education level, grazing area ratio, SF exposure, and access to fodder shed and animal shed are significantly different between adopters and non-adopters. Specifically, adopters have higher literacy rate and significantly more SF exposure, access to fodder and animal shed. Contrary to expectations, adopters also have a higher value of farm tools and a lower feed supplementary expense than non-adopters. Adopters have more than twice as much cow breeds and farm cart as their non-adopting counterparts. 
Table 1

Description and Summary Statistics for SF Adoption Decision

\begin{tabular}{|c|c|c|c|}
\hline VARIABLES & $\begin{array}{c}\text { Non-adopters } \\
\text { Mean }\end{array}$ & $\begin{array}{c}\text { Adopters } \\
\text { Mean }\end{array}$ & $\begin{array}{c}\mathrm{T}=\text { test } \\
\text { P-value }\end{array}$ \\
\hline Network (assistance from relatives/friends, ETB) & 1336.3 & 1508.8 & 0.7023 \\
\hline Gender ( $1=$ if household head is male) & 0.7643 & 0.8395 & 0.2973 \\
\hline Education ( $1=$ if household head is literate) & 3716 & 0.4545 & 0.0646 \\
\hline Credit ( $1=$ if household has access to credit in 2014/2015) & 0.2416 & 0.2834 & 0.2973 \\
\hline Cart ( $1=$ if household head owns cart tool) & 0.0906 & 0.1497 & 0.0406 \\
\hline Breed cow ( $1=$ if household head has cow breeds) & 0.0120 & 0.1122 & 0.0000 \\
\hline Information ( $1=$ if household owns Radio, TV and Mobile) & 0.1359 & 0.3048 & 0.0000 \\
\hline Fodder shed ( $1=$ if household head owns fodder shed) & 0.0060 & 0.0320 & 0.0209 \\
\hline Location ( $1=$ if household is located above $2000 \mathrm{~m}$ a.s.1.) & 0.0664 & 0.0588 & 0.7329 \\
\hline Distance to the nearest road (minute) & 34.38 & 28.27 & 0.0363 \\
\hline Household head age (years) & 57.66 & 57.26 & 028.27 \\
\hline Family labour & 82.31 & 91.19 & 0.1619 \\
\hline Farm income & 6689.5 & 5319.7 & 0.3284 \\
\hline Grazing area to household ratio & 0.0018 & 0.0012 & 0.0000 \\
\hline Distance to free grazing (minute) & 54.85 & 62.77 & 0.0310 \\
\hline Forage expense (ETB) & 143.59 & 112.2 & 0.1660 \\
\hline Total plots owned by the household (number) & 3.480 & 3.887 & 0.0236 \\
\hline Village experience of SF(year) & 3.214 & 4.331 & 0.0000 \\
\hline Distance to market (minuets) & 79.14 & 78.77 & 0.9407 \\
\hline Off-farm income & 3638.1 & 6678.8 & 0.2363 \\
\hline Value of all farm tools (ETB) & 549.89 & 797.01 & 0.0625 \\
\hline Farm size (ha) & 1.173 & 1.132 & 0.6835 \\
\hline Distance to nursery & 59.85 & 58.58 & 0.7863 \\
\hline Feed supplementary expense (ETB) & 144.07 & 112.70 & 0.0071 \\
\hline Total family size & 5.65 & 6.25 & 0.0071 \\
\hline Access to animal shed (yes $=1)$ & 0.0574 & 0.1122 & 0.0246 \\
\hline Veterinary expense (ETB) & 118.2 & 103.88 & 0.2018 \\
\hline \multicolumn{4}{|l|}{ Dependent variables in the first equation } \\
\hline Total milk production per household & 2.134 & 2.465 & 0.1376 \\
\hline Milk yield (litres per cow per day) & 1.459 & 1.699 & 0.0033 \\
\hline Lactation period (months) & 7.609 & 8.459 & 0.0000 \\
\hline Own milk and milk product consumption expenditure & 1549 & 1856 & 0.2101 \\
\hline Animal and animal product sale market participation $(\mathrm{yes}=1)$ & 0.514 & 0.540 & 0.5626 \\
\hline Keeping milking cows (yes=1) & 0.6465 & 0.7272 & 0.0595 \\
\hline Manure use $(\mathrm{kg})$ per household & 462.9 & 646.9 & 0.2214 \\
\hline
\end{tabular}

Source: own survey, 2015. 


\section{Endogenous Switching Regression Model}

Estimation of the economic gain of adoption of agricultural technologies, such as stall feeding based on non-experimental observations is not trivial because finding a proper counterfactual to treatment is the main challenge in impact evaluation. Adoption is a voluntary decision, where farmers themselves decide to adopt or not to adopt, based on the information they have. Therefore, adopters and non-adopters may be systematically different. When comparing adopters with non-adopters, adopters might differ on additional unobservable characteristics such as ability, awareness, information or motivation that could have a direct effect on the outcomes beyond adoption. That is, without stall feeding, outcomes might have been higher for adopters or lower for non-adopters, due to unobservable characteristics (Blundell and Costa Dias, 2000). Treating adoption as an exogenous variable and applying OLS would result in inconsistent parameter estimate.

The other econometric issue is that, even if we account for the endogeneity, it may not be proper to use a pooled model estimation which assumes that the set of covariates has the same impact on adopters and non-adopters. If it is assumed that covariates have differential effects on household outcome, separate welfare outcome functions for adopters and non-adopters have to be specified. The econometric problem will, therefore, contain both endogeneity (Hausman, 1978) and sample selection (Heckman, 1979). In general, the problem is that farmers in each of the two regimes are not the same with respect to variables that are correlated to the error term. This motivated the researchers to employ an ESR model used by Alene and Manyong (2007) following Lokshin and Sajaia (2004), which allows the researcher not only to simultaneously estimate the binary and continuous parts of the model in order to yield consistent standard errors but also to account for both endogeneity and sample selection bias based on joint normality of the error terms assumption.

Basically, ESR has two steps: the first step in the ESR is to specify the selection model so as to determine factors influencing stall feeding adoption based on a probit function by:

$D_{i}^{*}=Z_{i} \gamma+\varepsilon_{i}$

$D_{i}=1$ if $D_{i}^{*}>0 \quad$ (adoption of stall feeding)

$D_{i}=0$ if $D_{i}^{*} \leq 0 \quad$ (non-adoption of stall feeding)

where:

$D_{i}^{*}$ - is the latent variable for stall feeding adoption;

$D_{i}$ - is its observable counterpart which equals one if the farmer has adopted SF, and zero otherwise;

$Z_{i}$-are vectors of exogenous farm and non-farm characteristics determining adoption;

$\varepsilon_{i}-$ is a random disturbance associated with the adoption. 
The second step in the ESR is to define separate outcome functions for the two groups. The welfare functions can be expressed as:

Regime 1: $Y_{1 i}=X_{1 i} \beta_{1}+e_{1 i}$ if $D_{i}=1$ (outcome of stall feeding users)

Regime 2: $Y_{2 i}=X_{2 i} \beta_{2}+e_{2 i}$ if $D_{i}=0$ (outcome of non-stall feeding users)

where:

$X_{1}$ and $X_{2}$ - are vectors of weakly exogenous variables;

$\beta_{1}$ and $\beta_{2}-$ are vectors of parameters;

$e_{1}$ and $e_{2}-$ are random disturbance terms;

$Y_{1} \quad-$ represents outcomes measured in terms of milk produced and consumed, lactation period and animal market participation, etc.

Unfortunately, both $Y_{1}$ and $Y_{2}$ cannot be observed for a single animal at the same time. But the difference between the two is exactly what the author intends to discover, that is, the author is interested in (I) the difference between the outcome of the user compared with their expected outcome without stall feeding, and (II) the difference between what non-users benefit and their expected benefit if they were to adopt stall feeding. The mathematical explanation of these outcomes can be presented as:

$Y_{1 i}-\mathrm{E}\left(Y_{2 i} \mid D_{i}=1\right)$ (benefit of adopters)

$Y_{2 i}-\mathrm{E}\left(Y_{1 i} \mid D_{i}=0\right)$ (forgone benefit of non-adopters)

Assuming that $\varepsilon_{i}, \varepsilon_{1 i}$ and $\varepsilon_{2 i}$ have a trivariate normal distribution, with mean vector zero and the following covariance matrix:

$$
\operatorname{Cov}\left(\varepsilon_{1}, \varepsilon_{2}, \varepsilon_{0}\right)=\left[\begin{array}{ccc}
\sigma_{0}^{2} & \sigma_{01} & \sigma_{02} \\
\sigma_{10} & \sigma_{1}^{2} & \cdot \\
\sigma_{20} & \cdot & \sigma_{2}^{2}
\end{array}\right]
$$

where:

$\sigma_{1}^{2}$ and $\sigma_{2}^{2}-$ are variances of the error terms, $e_{1}$ and $e_{2}$;

$\sigma_{0}^{2} \quad-$ is the variance of the error term, $e_{0}$ which can be assumed to be equal to 1 since the coefficients are estimable only up to a scale factor (Lokshin and Sajaia, 2004);

$\sigma_{10} \quad-$ is the covariance of $e_{1}$ and $\varepsilon_{0}$;

$\sigma_{20} \quad-$ is the covariance of $\varepsilon_{2}$ and $\varepsilon_{0}$.

Since $Y_{1}$ and $Y_{2}$ are never observed simultaneously for a single cow or ox, the covariance between $\varepsilon_{1}$ and $\varepsilon_{2}$ is not defined and, therefore, indicated as dots in the covariance matrix and since the error term of the selection equation is correlated with the error terms of the outcome functions, the expected values of $e_{1}$ and $e_{2}$, conditional on the sample selection, are non-zero and are defined as: 


$$
\begin{aligned}
& E\left[e_{1 i} \mid D_{i}=1\right]=\sigma_{10} \frac{\phi\left(z_{i} \gamma\right)}{\Phi\left(z_{i} \gamma\right)}=\sigma_{10} \eta_{1 i} \\
& E\left[e_{1 i} \mid D_{i}=0\right]=\sigma_{20} \frac{\phi\left(z_{i} \gamma\right)}{\Phi\left(z_{i} \gamma\right)}=\sigma_{20} \eta_{2 i}
\end{aligned}
$$

Where $\phi$ and $\Phi($.$) are the standard normal probability density function and nor-$ mal cumulative density function, respectively. In this case, a statistical significance of the two estimated covariances $\hat{\sigma}_{10}$ and $\hat{\sigma}_{20}$, indicates that the decision to adopt and outcome variable are correlated implying the presence of endogenous switching, and the null hypothesis of the absence of sample selectivity bias is rejected. Full information maximum likelihood (FIML) method was employed for our estimation as it is a more efficient method of estimating endogenous switching, regression models (Lokshin and Sajaia, 2004). The logarithmic likelihood functions are given the assumption of trivariate normal distribution for the error terms:

$$
\begin{aligned}
& \ln \mathrm{L}_{i}=\sum_{i=1}^{N}\left\{D_{i}\left[\ln \phi\left(\frac{e_{1 i}}{\sigma_{1}}\right)-\ln \sigma_{1}+\ln \Phi\left(\theta_{1 i}\right)\right]+\left(1-D_{i}\right)\left[\ln \phi\left(\frac{e_{2 i}}{\sigma_{2}}\right)\right.\right. \\
& \left.\left.-\ln \sigma_{2}+\ln \left(1-\Phi\left(\theta_{2 i}\right)\right)\right]\right\}
\end{aligned}
$$

Where $: \theta_{j i}=\frac{z_{i} \gamma+\rho_{j} \varepsilon_{j i} / \sigma_{j}}{\sqrt{1-\rho_{j}^{2}}} \frac{1}{2}$, with $j=1,2$, and $\rho_{j}$ represent the correlation coefficient between the error terms $\varepsilon_{1}$, of the selection model and the error terms $e_{1 i}$ and $e_{2 i}$ of the outcome equation. Even if there is only one dependent variable, the set of exogenous variables in the first regression might be different from the set of exogenous variables in the second regression. Hence, both equations must be specified (Lokshin and Sajaia, 2004). In addition, we followed the usual order condition that $Z_{i}$ contains at least one variable not in $X_{i}$ imposing an exclusion restriction on Equation (14). These variables do not have any direct effect on the outcome variable, although they are hypothesized to affect the probability that the household adopts the improved technology.

The use of endogenous switching regression model has an additional advantage in comparing the expected outcome of adopters (I) with respect to the households that did not adopt (II), and to investigate the expected outcome in the counterfactual hypothetical cases (III) that the adopted households did not adopt, and (IV) that the non-adopters households adopted. Thus, the conditional expectations for our outcome variables in the four cases are denoted as:

(I) $\quad E\left(Y_{1 i} \mid D_{i}=1\right)=X_{1 i} \beta_{1}+\sigma_{10} \eta_{1 i}$

(II) $\quad E\left(Y_{2 i} \mid D_{i}=0\right)=X_{2 i} \beta_{2}+\sigma_{20} \eta_{2 i}$

(III) $\quad E\left(Y_{2 i} \mid D_{i}=1\right)=X_{1 i} \beta_{2}+\sigma_{20} \eta_{1 i}$

(IV) $\quad E\left(Y_{1 i} \mid D_{i}=0\right)=X_{2 i} \beta_{1}+\sigma_{10} \eta_{2 i}$ 
Cases (I) and (II) indicate the actual expectations observed in the sample, whereas cases (III) and (IV) represent the counterfactual expected outcomes. Furthermore, the effect of the treatment "to adopt" on the treated (TT) is calculated as the difference between (I) and (III), and the effect of the treatment of the untreated (TU), for the households that actually did not adopt, as the difference between (IV) and (II), the procedures taken by Heckman (2001) and Di Falco et al. (2013) that compares the performance of climate change adaptation strategies in Ethiopian agriculture via calculating ATT and ATU:

$$
\begin{array}{ll}
\text { (II) } & T T=E\left(Y_{1 i} \mid D_{i}=1\right)-E\left(Y_{2 i} \mid D_{i}=1\right)=X_{1 i}\left(\beta_{1}-\beta_{2}\right)+\left(\sigma_{10}-\sigma_{20}\right) \eta_{1 i} \\
\text { (III) } & T U=\left(Y_{1 i} \mid D_{i}=0\right)-E\left(Y_{2 i} \mid D_{i}=0\right)=X_{2 i}\left(\beta_{1}-\beta_{2}\right)+\left(\sigma_{10}-\sigma_{20}\right) \eta_{2 i} \\
\text { (IV) } & B H_{1}=\left(Y_{1 i} \mid D_{i}=1\right)-E\left(Y_{1 i} \mid D_{i}=0\right)=\left(X_{1 i}-X_{2 i}\right) \beta_{1 I}+\sigma_{10}\left(\eta_{1 i}-\eta_{2 i}\right) \\
\text { (V) } & B H_{2}=\left(Y_{1 i} \mid D_{i}=1\right)-E\left(Y_{2 i} \mid D_{i}=1\right)=\left(X_{1 i}-X_{2 i}\right) \beta_{2 I}+\sigma_{20}\left(\eta_{1 i}-\eta_{2 i}\right)
\end{array}
$$

\section{Empirical result}

We first focus on the adoption of SF in the selection equation. Secondly, we explain the factors affecting the outcome variables estimated by equations, depending on whether farmers are adopters and non-adopters. Finally, we estimate ATT for adopters and ATU for non-adopters by equation.

\section{Determinates of adoption and outcome variables}

The estimates of the determinants of adoption and milk outcome variables are presented in Tables 2. As noted previously, the FIML method estimates both the adoption and the outcome equations jointly. Results from the selection equations are discussed first. The estimated results for the probability of adopting the technology are generally in agreement with our earlier expectation. In all specifications, the same variables have statistically similar effects on adoption. The correlation coefficients, $\rho_{1}$ and $\rho_{2}$, between the error terms of the selection and outcome equations are reported in the bottom section of the same table as an indication of selection bias. A statistical significance of any of them signalled to account for self-selection issue. The correlation coefficients for the adopters $\left(\rho_{1}\right)$ and non-adopters $\left(\rho_{2}\right)$ equations are both negative but statistically insignificant, suggesting that both groups are not better or worse off than a random farm household. The insignificance of the likelihood ratio tests for independence of equations also proved that there is no joint dependence between the selection equations and the outcome equations for adopters and non-adopters (Table 2) as in the case of Di Falco et al. (2013).

However, the differences in milk production (Table 2) and consumption (Table 3) equation coefficients, between the farm households that adopted and those that did not adopt, illustrate the presence of heterogeneity in the sample. The selection results are only discussed briefly as our main objective is to evaluate the impacts on different outcomes. Column (3) of Table 2 shows that factors influencing the household decision to participate in FSS are: zonal variation and 
access to information, animal feed shed, cow breed, village exposure to SF, animal shock and location, forage use and total feed value. The variable representing information is positive and significantly different from zero, suggesting that more-informed farmers are more likely to adopt FSF, consistent with the findings of (Deressa, Hassan, Ringler, Alemu and Yesuf, 2009; Gunte, 2015; Muuz, 2017), who revealed a positive relation between access to information and technology adoption in Ethiopia. The variable access to animal feed shed is also positive and statistically significant in the selection model, indicating that farmers with feed shed are more likely to adopt the technology.

The possession of improved cow and animal shock exposure, forage expense and total feed value are statistically significant variables with a positive sign, inducing farming households to adopt SF technology. As noted by Turinawe et al. (2011) in Uganda and Muuz (2017) In Ethiopia, adoption of SF was significantly and positively influenced by the number of cow breeds, and relevant findings of Holden and Westberg (2016) indicated that cereal plantation and fertilizer application were positively correlated with risk aversion for net buyers of food in Ethiopia. Ayenew et al. (2015) found that farmers with a higher level of relative risk premium were more likely to opt for crop diversification in Ethiopia. Farmers living in lowland areas showed more interest in the SF use and this opposes the results of Bishu (2014) once zonal variation is controlled.

Smallholder farmers in Ethiopia mainly depend on grazing land and crop residue to feed their animals (Tegegne et al., 2013). The estimation results show that grazing area ratio, access to animal feed shed and cow breeds, positively affect milk production of adopters. Makoni, Mwai, Redda, van der Zijpp and van der Lee (2014) argue that the increase in milk production may have come mainly from increased the number of cows rather than increased productivity, while Adane, Shiferaw and Gebremedhin (2015) indicated that higher grazing land area and the number of cow breeds per household were positively associated with higher milk output in Ethiopia.

The variables of hired labor and family labor had opposite signs with hired labour having a negative effect and family labor having a positive effect on milk output of non-adopters. Adane et al. (2015) and del Corral, Perez and Roibás (2011) found that there is a strong relationship between family labor and milk production. In addition, the zonal variation, in which households reside, determines the level of household milk production for both groups negatively. The availability of fodder shed and purchased supplements are also found to have unexpected negative effects on milk production, mainly for adopters. This result is inconsistent with other studies on milk production (Adane et al., 2015; del Corral et al., 2011). 
Table 2

Endogenous Switching for FSF adoption and Milk Production

\begin{tabular}{|c|c|c|c|}
\hline \multirow{2}{*}{ VARIABLES } & $(\mathrm{FSF}=1)$ & $(\mathrm{FSF}=0)$ & $(\mathrm{FSF}=1 / 0)$ \\
\hline & Milk yield & Milk yield & Selection \\
\hline \multirow[t]{2}{*}{ Province 5 (South East) } & -0.463 & $-0.770 * * *$ & $0.948 * *$ \\
\hline & $(0.309)$ & $(0.182)$ & $(0.370)$ \\
\hline \multirow[t]{2}{*}{ Province 3 (Central) } & $-0.748 * * *$ & $-0.826 * * *$ & $1.564 * * *$ \\
\hline & $(0.270)$ & $(0.275)$ & $(0.396)$ \\
\hline \multirow[t]{2}{*}{ Province 2 (Eastern) } & $-0.683 * * *$ & $-0.887 * * *$ & $0.760 * *$ \\
\hline & $(0.222)$ & $(0.187)$ & $(0.353)$ \\
\hline \multirow[t]{2}{*}{ Province 4 (North West) } & -0.396 & $-0.685^{* * *}$ & $0.458^{*}$ \\
\hline & $(0.257)$ & $(0.143)$ & $(0.252)$ \\
\hline \multirow[t]{2}{*}{ Total cows } & 0.0316 & -0.0367 & -0.0534 \\
\hline & $(0.0618)$ & $(0.0268)$ & $(0.0690)$ \\
\hline \multirow[t]{2}{*}{ Hired labour } & 0.138 & $-0.240 * * *$ & 0.0499 \\
\hline & $(0.140)$ & $(0.0902)$ & $(0.178)$ \\
\hline \multirow[t]{2}{*}{ Grazing area to household ratio } & $48.27 * *$ & 13.99 & -35.00 \\
\hline & $(24.02)$ & $(13.73)$ & $(49.72)$ \\
\hline \multirow[t]{2}{*}{ Total animal feed value (ETB) } & $-9.02 \mathrm{e}-06$ & $1.06 \mathrm{e}-05$ & $3.43 \mathrm{e}-05^{* * *}$ \\
\hline & $(1.01 \mathrm{e}-05)$ & $(8.00 \mathrm{e}-06)$ & $(1.15 \mathrm{e}-05)$ \\
\hline \multirow[t]{2}{*}{ Forage expense (ETB) } & -0.0657 & -0.00264 & $0.357 *$ \\
\hline & $(0.159)$ & $(0.114)$ & $(0.183)$ \\
\hline \multirow[t]{2}{*}{ Feed supplementary cost (ETB) } & 0.000250 & $-0.000161 * * *$ & $-1.00 \mathrm{e}-05$ \\
\hline & $(0.000154)$ & $(5.25 \mathrm{e}-05)$ & $(0.000153)$ \\
\hline \multirow[t]{2}{*}{ Veterinary expenses (ETB) } & -0.00144 & 0.000406 & -0.000599 \\
\hline & $(0.00148)$ & $(0.000263)$ & $(0.000755)$ \\
\hline \multirow[t]{2}{*}{ Location (highland=1) } & 0.241 & 0.155 & $-0.754 *$ \\
\hline & $(0.237)$ & $(0.206)$ & $(0.448)$ \\
\hline \multirow[t]{2}{*}{ Breed cow $($ yes=1) } & $0.471^{*}$ & -0.381 & $1.556^{* * *}$ \\
\hline & $(0.278)$ & $(0.271)$ & $(0.383)$ \\
\hline \multirow[t]{2}{*}{ Access to pond (yes=1) } & -0.140 & $-0.387^{*}$ & -0.449 \\
\hline & $(0.200)$ & $(0.233)$ & $(0.767)$ \\
\hline \multirow[t]{2}{*}{ Access to animal shed (yes=1) } & $0.520 * *$ & -0.161 & 0.336 \\
\hline & $(0.209)$ & $(0.141)$ & $(0.334)$ \\
\hline \multirow[t]{2}{*}{ Access to fodder shed (yes=1) } & $-0.534 * * *$ & $-0.605^{* *}$ & $1.732 * *$ \\
\hline & $(0.161)$ & $(0.255)$ & $(0.699)$ \\
\hline \multirow[t]{2}{*}{ Household head age (year) } & 0.000937 & 0.00166 & -0.00430 \\
\hline & $(0.00523)$ & $(0.00289)$ & $(0.00578)$ \\
\hline Animal shock exposure (yes $=1$ ) & -0.122 & 0.189 & $0.473 * *$ \\
\hline
\end{tabular}


cont. Table 2

\begin{tabular}{lccc}
\hline \multirow{2}{*}{ VARIABLES } & $(\mathrm{FSF}=1)$ & $(\mathrm{FSF}=0)$ & $(\mathrm{FSF}=1 / 0)$ \\
\cline { 2 - 4 } & Milk yield & Milk yield & Selection \\
\hline Information access (yes=1) & $(0.00123)$ & $(0.000550)$ & $(0.00105)$ \\
& & & $0.381^{* *}$ \\
Village exposure to SF (years) & & & $(0.186)$ \\
& & & $0.144^{* *}$ \\
Constant & $2.081^{* * *}$ & $1.863^{* * *}$ & $(0.0705)$ \\
& $(0.381)$ & $(0.182)$ & $-1.638^{* * *}$ \\
lns1, lns2 & $-0.271(0.132)^{* *}$ & $-0.556(0.164)^{* * *}$ & $(0.464)$ \\
$\boldsymbol{\rho}_{\mathbf{1}}, \boldsymbol{\rho}_{2}$ & $-0.363(0.266)$ & $0.166(0.354)$ & \\
LR test of indep. eqns (PV) & & 0.2058 & \\
\hline
\end{tabular}

NB: Robust standard errors in parentheses and $* * * p<0.01, * * p<0.05, * \mathrm{p}<0.1$ indicate level of significance at 1,5 , and 10 .

Source: own survey, 2015.

Referring to Table 3, the ESR estimate for the milk and meat product consumption expenditure indicated that the correlation coefficients between the error terms in the selection and the outcome equations $\left(\rho_{1}\right.$ and $\left.\rho_{2}\right)$ are not statistically different from zero - implying that the switch is not endogenous. Expectedly, an increase in household herd size results in an increment of 155 ETB consumption expenditure for adopters while higher total food expenditure contributes positively to consumption expenditure. This finding is in consonance with economic theory, which posits that farmers with higher asset spend more on consumer goods and is in conformity with the literature findings of milk consumption expenditure (Oni and Fashogbon, 2012; Aidoo, Nurah, Fialor and Ohene-Yankyera, 2009).

A similar relationship was also reported in Kenya, where dairy cow ownership increased consumption of milk products by 1.0 litre per week (Nicholson et al., 2004). The results also showed that adopting male farmers recorded a significant consumption expenditure in milk and milk products in line with the results of Oni and Fashogbon (2012). A positive effect was observed between household total food expenditure and the level of milk consumption expenditure. This finding was in agreement with the result of Oni and Fashogbon (2012), where they reported that as food expenditure increases the consumption of milk and milk products expenditure increases in Nigeria. 
Table 3

Endogenous Switching for FSF adoption and milk and meat consumption expenditure

\begin{tabular}{|c|c|c|c|}
\hline \multirow{2}{*}{ VARIABLES } & $(\mathrm{FSF}=1)$ & $(\mathrm{FSF}=0)$ & $(\mathrm{FSF}=1 / 0)$ \\
\hline & Consumption & Consumption & Selection \\
\hline \multirow[t]{2}{*}{ Family size } & 18.36 & 31.65 & 0.0445 \\
\hline & $(98.52)$ & $(47.64)$ & $(0.0332)$ \\
\hline \multirow[t]{2}{*}{ Household head sex $($ male $=1)$} & $751.5^{* *}$ & -102.2 & $0.401^{*}$ \\
\hline & $(341.2)$ & $(262.0)$ & $(0.214)$ \\
\hline \multirow[t]{2}{*}{ Household head age (years) } & -16.44 & 5.832 & -0.00239 \\
\hline & $(10.13)$ & $(8.664)$ & $(0.00513)$ \\
\hline \multirow[t]{2}{*}{ Household head education $(1 / 0)$} & -374.3 & -99.19 & 0.0350 \\
\hline & $(362.6)$ & $(298.7)$ & $(0.155)$ \\
\hline \multirow[t]{2}{*}{ Total food expenditure (ETB) } & $0.0823 * * *$ & $0.0413 * * *$ & $1.81 \mathrm{e}-06$ \\
\hline & $(0.0208)$ & $(0.0138)$ & $(3.19 \mathrm{e}-06)$ \\
\hline \multirow[t]{2}{*}{ Farm size (ha) } & -63.41 & 71.42 & 0.0310 \\
\hline & $(84.29)$ & $(155.7)$ & $(0.0582)$ \\
\hline \multirow[t]{2}{*}{ Total farm income (ETB) } & 0.0401 & -0.00273 & $-7.93 e-06$ \\
\hline & $(0.0381)$ & $(0.00253)$ & $(6.06 \mathrm{e}-06)$ \\
\hline \multirow[t]{2}{*}{ Total off-farm income } & 0.0226 & -0.00336 & $-3.90 \mathrm{e}-06$ \\
\hline & $(0.0187)$ & $(0.00315)$ & $(5.67 e-06)$ \\
\hline \multirow[t]{2}{*}{ Religion of household head (orthodox=1) } & -593.2 & -51.60 & $0.488 * *$ \\
\hline & $(623.1)$ & $(317.1)$ & $(0.211)$ \\
\hline \multirow[t]{2}{*}{ Location of household (highland=1) } & 713.0 & -174.8 & $-1.080 * *$ \\
\hline & (791.4) & $(203.5)$ & $(0.451)$ \\
\hline \multirow[t]{2}{*}{ Information access (TV, Radio \& mobile $=1)$} & 148.6 & 124.4 & $0.546 * * *$ \\
\hline & $(395.2)$ & $(357.8)$ & $(0.183)$ \\
\hline \multirow[t]{2}{*}{ Herd size (TLU) } & $155.4 * * *$ & $186.9 * * *$ & -0.0216 \\
\hline & $(59.18)$ & $(49.73)$ & $(0.0237)$ \\
\hline \multirow[t]{2}{*}{ Access to formal credit (yes=1) } & 737.2 & 122.5 & -0.0302 \\
\hline & $(482.0)$ & $(272.3)$ & $(0.168)$ \\
\hline \multirow[t]{2}{*}{ Animal shock experience (yes=1) } & -182.0 & -130.3 & $0.338^{*}$ \\
\hline & $(363.8)$ & $(362.8)$ & $(0.183)$ \\
\hline \multirow[t]{2}{*}{ Distance to free grazing land (minute) } & & & 0.00168 \\
\hline & & & $(0.00183)$ \\
\hline \multirow[t]{2}{*}{ Exposure of SF (years) } & & & $0.322 * * *$ \\
\hline & & & $(0.0560)$ \\
\hline \multirow[t]{2}{*}{ Constant } & 1,038 & -261.2 & $-2.587 * * *$ \\
\hline & $(1,251)$ & $(503.9)$ & $(0.503)$ \\
\hline $\operatorname{lns} 1, \operatorname{lns} 2$ & $7.552(0.045)^{* * *}$ & $7.527(0.0001)^{* * *}$ & \\
\hline$\rho_{1}, \rho_{2}$ & $-0.318(0.280)$ & $0.0023(0.124)$ & \\
\hline LR test of indep. eqns (PV) & & 0.1434 & \\
\hline
\end{tabular}

NB: Robust standard errors in parentheses and $* * * p<0.01, * * p<0.05,{ }^{*} p<0.1$ indicate level of significance at 1,5 , and 10 .

Source: own survey, 2015. 
The ESR empirical results for the probability of participating in animal and animal product sale in Table 4 showed that participation in animal and animal product markets were greatly influenced by family size, distance to market, cattle size, population density, animal shock, agroecological location and zonal variation, and not so much by human capital. Farmers with more family members and higher cow numbers living in the highland, participated more intensively in the animal market. However, ownership of oxen and animal shock experience reduced participation in the market for animals and animal products. These findings reinforce the findings of Ehui, Benin and Paulos (2003) and Kuma, Baker, Getnet and Kassa (2014) where they found that oxen holding reduced dairy product sale, while cow stock increased live animal or dairy product sale in Ethiopia.

A negative relationship was also reported between population density and market participation (Ehui et al., 2003). In a similar study area, Ehui et al. (2003) also showed that farmer participation in livestock market sales was positively associated with long distance to market and higher population density. As expected, animal shock exposure was found to have an inverse relationship with participation in the animal market. However, farmers living in the highland unexpectedly appeared to have a high probability of participation in an animal sale market than people from the lowland (Tegebu et al., 2012). In confirming with our expectations, belonging to Southern and Northwestern zones, which are relatively endowed with population livestock in the region, increased the probability of participating in an animal market.

Table 4

Endogenous Switching for FSF adoption and animal and animal product sale market participation

\begin{tabular}{lccc}
\hline \multirow{2}{*}{ VARIABLES } & $(\mathrm{FSF}=1)$ & $(\mathrm{FSF}=0)$ & $(\mathrm{FSF}=1 / 0)$ \\
\cline { 2 - 4 } & Participation & Participation & Selection \\
\hline Distance to market (minutes) & 0.000197 & $0.00262^{*}$ & -0.000370 \\
Distance to the nearest road (minutes) & $(0.00180)$ & $(0.00137)$ & $(0.00126)$ \\
& 0.00186 & 0.000615 & $-0.00338^{*}$ \\
Population density (ratio) & $(0.00260)$ & $(0.00193)$ & $(0.00187)$ \\
& -0.000125 & $-0.000142^{*}$ & 0.000109 \\
Household head age (years) & $(0.000117)$ & $(8.17 \mathrm{e}-05)$ & $(8.21 \mathrm{e}-05)$ \\
& 0.00356 & 0.00432 & -0.00853 \\
Household head sex (male=1) & $(0.00587)$ & $(0.00543)$ & $(0.00523)$ \\
Family size & -0.281 & 0.0124 & $0.563 * * *$ \\
Household head education (literate=1) & $(0.239)$ & $(0.204)$ & $(0.174)$ \\
& 0.00752 & $0.0950^{* * *}$ & 0.00707 \\
& $(0.0386)$ & $(0.0340)$ & $(0.0283)$ \\
& 0.111 & -0.0786 & -0.0407 \\
\hline
\end{tabular}




\begin{tabular}{|c|c|c|c|}
\hline Total oxen number & $\begin{array}{l}-0.0289 \\
(0.0540)\end{array}$ & $\begin{array}{l}-0.118 * * \\
(0.0572)\end{array}$ & $\begin{array}{c}0.0218 \\
(0.0440)\end{array}$ \\
\hline Total cow number & $\begin{array}{c}0.130 * \\
(0.0718)\end{array}$ & $\begin{array}{c}0.0595 \\
(0.0547)\end{array}$ & $\begin{array}{l}-0.00641 \\
(0.0458)\end{array}$ \\
\hline Farm size (ha) & $\begin{array}{c}0.101 \\
(0.114)\end{array}$ & $\begin{array}{l}-0.0839 \\
(0.0965)\end{array}$ & $\begin{array}{c}0.0646 \\
(0.0629)\end{array}$ \\
\hline Breed cow $($ yes $=1)$ & $\begin{array}{c}-1.028 * * * \\
(0.326)\end{array}$ & $\begin{array}{l}0.0187 \\
(0.868)\end{array}$ & $\begin{array}{c}1.849 * * * \\
(0.334)\end{array}$ \\
\hline Information access $(\mathrm{TV} \&$ radio $=1)$ & $\begin{array}{l}-0.166 \\
(0.190)\end{array}$ & $\begin{array}{l}-0.196 \\
(0.216)\end{array}$ & $\begin{array}{c}0.423 * * * \\
(0.164)\end{array}$ \\
\hline Mean milk price (ETB) & $\begin{array}{l}-0.000983 \\
(0.00306)\end{array}$ & $\begin{array}{l}-0.000483 \\
(0.00210)\end{array}$ & $\begin{array}{l}-0.000862 \\
(0.00280)\end{array}$ \\
\hline Social network (got assistance $=1$ ) & $\begin{array}{l}-1.48 \mathrm{e}-06 \\
(1.71 \mathrm{e}-05)\end{array}$ & $\begin{array}{l}-1.34 \mathrm{e}-05 \\
(1.72 \mathrm{e}-05)\end{array}$ & $\begin{array}{c}1.38 \mathrm{e}-05 \\
(1.63 \mathrm{e}-05)\end{array}$ \\
\hline Access to formal credit (yes $=1$ ) & $\begin{array}{l}-0.0837 \\
(0.192)\end{array}$ & $\begin{array}{l}0.0857 \\
(0.168)\end{array}$ & $\begin{array}{l}0.0689 \\
(0.144)\end{array}$ \\
\hline Province 1 (Southern) & $\begin{array}{l}1.106^{* *} \\
(0.439)\end{array}$ & $\begin{array}{c}0.439 \\
(0.362)\end{array}$ & $\begin{array}{c}-1.383^{* * *} \\
(0.300)\end{array}$ \\
\hline Province 2(Eastern) & $\begin{array}{l}-0.127 \\
(0.268)\end{array}$ & $\begin{array}{l}-0.0886 \\
(0.288)\end{array}$ & $\begin{array}{c}-0.459 * \\
(0.279)\end{array}$ \\
\hline Province 3 (Central) & $\begin{array}{l}-0.146 \\
(0.267)\end{array}$ & $\begin{array}{l}-0.150 \\
(0.463)\end{array}$ & $\begin{array}{l}0.510^{*} \\
(0.265)\end{array}$ \\
\hline Province 4 (North West) & $\begin{array}{l}0.502 * \\
(0.277)\end{array}$ & $\begin{array}{c}0.189 \\
(0.275)\end{array}$ & $\begin{array}{c}-0.580 * * * \\
(0.221)\end{array}$ \\
\hline Location of household (highland=1) & $\begin{array}{l}0.601 * \\
(0.339)\end{array}$ & $\begin{array}{c}0.613 * * \\
(0.310)\end{array}$ & $\begin{array}{c}-0.585 * * \\
(0.296)\end{array}$ \\
\hline Animal shock experience(yes=1) & $\begin{array}{c}-0.527 * * * \\
(0.197)\end{array}$ & $\begin{array}{l}-0.120 \\
(0.211)\end{array}$ & $\begin{array}{c}0.435 * * * \\
(0.159)\end{array}$ \\
\hline Distance to free grazing land (minute) & & & $\begin{array}{c}0.00515^{* * *} \\
(0.00152)\end{array}$ \\
\hline Exposure of SF (years) & & & $\begin{array}{c}0.214 * * * \\
(0.0504)\end{array}$ \\
\hline Constant & $\begin{array}{c}0.698 \\
(0.467)\end{array}$ & $\begin{array}{c}-0.899 * \\
(0.503)\end{array}$ & $\begin{array}{c}-1.356^{* * *} \\
(0.506)\end{array}$ \\
\hline $\begin{array}{l}\text { rho1, rho0 } \\
\text { LR test of indep. eqns (PV) }\end{array}$ & $-14.19(1.550)^{* * *}$ & $\begin{array}{c}-0.625(0.519) \\
0.0005\end{array}$ & \\
\hline
\end{tabular}

NB: Robust standard errors in parentheses and ${ }^{* * *} \mathrm{p}<0.01, * * \mathrm{p}<0.05,{ }^{*} \mathrm{p}<0.1$ indicate level of significance at 1,5 , and 1 .

Source: own survey, 2015. 


\section{Impact of FSF and SSF adoption}

Estimated impacts of full and seasonal stall feeding adoption are presented in Table 5. The predicted outcomes from the ESR models are used to compute both the average treatment effect on the treated (ATT) and average treatment effect on the non-treated (ATU). ESR results also demonstrate that SF has mixed impacts on economic indicators (milk production and consumption, lactation period) and market participation in the animal sale and animal shock. We estimated endogenous switching regression (ESR) to control for selection bias from both observable and unobservable factors by the full information maximum likelihood (FIML) method (Lokshin and Sajaia, 2004) and model results are presented in Table 5. We first discuss the results from the continuous outcomes followed by estimates for the binary outcomes.

Table 5

Impact of SF on milk production and consumption; and animal market participation

\begin{tabular}{|c|c|c|c|c|c|c|c|}
\hline \multirow{2}{*}{$\begin{array}{l}\text { Outcome } \\
\text { Indicator }\end{array}$} & & \multicolumn{2}{|c|}{ Decision on FSFa } & \multirow{2}{*}{$\begin{array}{c}\text { Treatment } \\
\text { effect }\end{array}$} & \multicolumn{2}{|c|}{ Decision on $\mathrm{SSF}^{\mathrm{b}}$} & \multirow{2}{*}{$\begin{array}{l}\text { Treatment } \\
\text { Effect }\end{array}$} \\
\hline & & Adopt & Not adopt & & Adopt & Not adopt & \\
\hline \multirow{2}{*}{$\begin{array}{l}\text { Milk } \\
\text { production (L) }\end{array}$} & Participants & 2.4661 & 2.0198 & $0.4462 * * *$ & 1.9045 & -0.1487 & $2.0533^{* *}$ \\
\hline & Non-participants & 4.4336 & 2.1350 & $2.2986 * * *$ & 2.2169 & 1.2217 & $0.9952 * * *$ \\
\hline \multirow{2}{*}{ Milk yield } & Participants & 1.6993 & 1.4064 & $0.2928 * * *$ & 1.7419 & -0.0210 & $1.7630 * * *$ \\
\hline & Non-participants & 2.1696 & 1.4592 & $0.7104 * * *$ & 0.2884 & 1.3935 & $-1.1051 * * *$ \\
\hline \multirow{2}{*}{$\begin{array}{l}\text { Lactation } \\
\text { inmonths }\end{array}$} & Participants & 8.4598 & 8.1712 & $0.2886^{* * *}$ & 8.3298 & 8.7293 & $-0.3995 * * *$ \\
\hline & Non-participants & 8.6022 & 7.6087 & $0.9935 * * *$ & 8.3292 & 7.2554 & $1.0737 * * *$ \\
\hline \multirow{2}{*}{$\begin{array}{l}\text { Milk and Meat } \\
\text { consumption }\end{array}$} & Participants & 1855.6 & 1587.9 & $267.7 * * *$ & 1807.8 & 1254.5 & $553.2 * * *$ \\
\hline & Non-participants & 2777.4 & 1548.9 & $1228.4 * * *$ & 2141.8 & 1470.3 & $671.5 * * *$ \\
\hline \multirow{2}{*}{$\begin{array}{l}\text { Animal sale } \\
(1 / 0)\end{array}$} & Participants & ATT & & $0.2945^{* * *}$ & & & $0.1604 * * *$ \\
\hline & Non-participants & ATU & & $0.4782 * * *$ & & & $0.4061 * * *$ \\
\hline
\end{tabular}

$\mathrm{NB}: * * *, * *$ and $*$ indicate the level of significance for $1 \%, 5 \%$ and $10 \%$, respectively;

${ }^{\mathrm{a}} \mathrm{FSF}=$ Full-Year Stall Feeding adoption, and ${ }^{\mathrm{b}} \mathrm{SSF}=$ Seasonal-Stall Feeding adoption.

Source: own survey, 2015.

Considering the case of full adoption (FSF), households that adopted SF would have harvested $0.39(21.7 \%)$ litres/cow less in the case of FSF and 2 litres/cow in the case of SSF had they not adopted; their lactation period would have declined by $0.29(3.5 \%)$ months, respectively. Had non-participants chosen to adopt, they would have increased their milk harvest by 2.3 litres per cow and their lactation period would have increased by 1 month. The result that SF positively influences milk production and lactation is a confirmation that SF contributes to boosting productivity. The additional average gain for adopters at household level due to SSF adoption is about ETB 11,827 per average lactation period $(1.76 * 2$ cows*14 ETB*240 days), where 2 is the average milking cow, 14 is the price of milk per litre of milk and 240 days is an average lactation period in the study area. This is consistent with the idea that adoption of new agricultural technology can improve household wel- 
fare (Shiferaw, Kassie, Jaleta, and Yirga, 2014; Khonje, Manda, Alene and Kassie, 2015; Wambugu et al., 2011).

We also observe a positive and significant impact of SF on households' milk and milk product consumption expenditure. The same Table shows that farmers who adopt FSF and SSF would have spent about 268 ETB and 553 ETB less on meat and milk products if they had not adopted. The ATU estimates show that farm households who did not adopt would have spent about 1228 ETB more on meat and milk products if they had adopted. Our results are similar to previous studies that have used different estimation methods and have found a positive effect of stall feeding on the use of inputs (Wambugu et al., 2011) in Kenya and (Turinawe et al., 2011) in Uganda.

Consistent with our expectations, the results further show that adoption of SF significantly increased the probability of selling animal and animal product by $29 \%$ for adopters. For non-adopters, the ATU estimates show that the probability of market participation would have been $47 \%$ higher had they adopted the technology. A similar result was obtained by Wambugu et al. (2011) in Kenya and Turinawe et al. (2011) in Uganda, who found a higher volume of animal and product sale in SF users.

\section{Conclusions}

In this paper, efforts were made to assess the impact of full (FSF) and seasonal (SSF) stall feeding technology on households' milk production and consumption, and market participation in rural Northern Ethiopia, using data from 518 rural farmers collected in 2015, by applying endogenous switching regression model. First, the existence of initial differences in explanatory and outcome variables among households was examined using descriptive analysis of the data. The overall result indicated that SF adoption ensures mixed benefits in response to differences in factor endowments, household characteristics, farm attributes and location factors, which create differences in marginal benefit, and the resulting differences in marginal benefit induce farm households to adopt SF.

We found that the SF adoption is positively influenced by animal feed value, zonal variation, gender, family size, off-farm income, access to information and fodder shed, forage expense, cow breed possession, animal shock, distance to grazing land and early SF exposure, but negatively associated with total land and herd size, geographic location, distance to road. The results also indicate that adoption of breed cow, availability of grazing land, family and hired labor, agro-ecology, access to animal and fodder shed determine the amount of milk production. With regard to milk and milk product consumption expenditure, the findings have revealed that household total food expenditure, herd size and gender has been proven to increase consumption expenditure. In examining factors affecting animal market participation in sales, the results show that ownership of cattle, population density, family size, agro-ecology location, distance to market and animal shock experience are the main factors influencing market participation in animal sales.

Using ESR models, we estimate different outcome indicators for both adopters 
from adoption (ATT), and non-adopters had they adopted (ATU). The adoption of FSF and SSF leads to significant gains in milk production and consumption expenditure, lactation period, and animal market participation. It is identified that there would be a decline of $21 \%$ in milk production if adopters would not have adopted this technology. On the other hand, non-adopters could increase their milk production and productivity by $100 \%$ and $48 \%$, if they would adopt this technology. The results further show that SF adoption had significant lactation period-increasing impacts for adopters and non-adopters, if they were to adopt the technology.

An increase in consumption expenditure by $17 \%$ from FSF and $44 \%$ in the case of SSF could be considered significant on livelihoods for smallholder farmers in Tigrai and such a positive impact should not be ignored. Among adopters, the adoption of SF increased the likelihood of participating in an animal sale market by $29 \%$, while non-adopters would have increased their participation by $47 \%$ had they decided to adopt.

These findings demonstrate the importance of SF technology for enhancing cattle performance (milk production and consumption, lactation) and market participation (animal live and animal product) of smallholder farmers in semi-arid areas. This paper highlights the important nexus between household's decision on livestock production, and technology introduction and adoption. Local and regional policies that can enable local farmers to respond to land degradation and livestock shocks should promote and support full scale SF adoption. Therefore, wider adoption of SF has great potential for transforming the agricultural sector in general and the welfare of small rural farmers in the region. The policy implication of our results is that the national government should consider embracing SF as one of the priority farming packages in its national extension agenda and develop policies which overcome limitations for wider expansion. Policies that promote livestock production and soil conservation should promote full scale SF adoption and expansion.

Acknowledgements: This research has been sponsored by the collaborative research and capacity-building project on Climate Smart Natural Resource Management and Policy (NORHED-CLISNARP) between Mekelle University and Norwegian University of Life Sciences. The NORHED-CLISNARP project and this research is funded by the Norwegian Agency for Development Cooperation (NORAD) and the Quota Scholarship programme of StatensLånekasse for Utdanning. Special thanks go to my Supervisor Professor Stein Holden (NMBU), Norway for his unreserved advice and my Co-Advisor, Dr. Mesfin Tilahun (MU) for his assistance. 


\section{References}

Adane, Z., Shiferaw, K., Gebremedhin, B. (2015). Sources of technical inefficiency of smallholder farmers in milk production in Ethiopia. LIVES Working Paper 3. Nairobi, Kenya: ILRI.

Aidoo, R., Nurah, G.K., Fialor, S.C., Ohene-Yankyera, K. (2009). Determinants of dairy consumption expenditure in urban communities of Southern Ghana. Journal of Science and Technology 29(1).

Alene, A.D., Manyong, V.M. (2007). The effects of education on agricultural productivity under traditional and improved technology in northern Nigeria: an endogenous switching regression analysis. Empirical economics 32(1), pp. 141-159.

Ayenew, H.Y., Sauer, J., Abate-Kassa, G. (2015). Exposure to Risk and Risk Management in Smallholder Agriculture. In 55 $5^{\text {th }}$ Annual Conference, Giessen, Germany (No. 209211). German Association of Agricultural Economists.

Baltenweck, I., Tenywa, J.S., Mugisha, J. (2007). Dairy Farming in Uganda: Production Efficiency and Soil Nutrients under Different Farming Systems. Vol. 1. ILRI (aka ILCA and ILRAD), Nairobi, Kenya.

Behnke, R.H., Metaferia, F. (2011). The contribution of livestock to the Ethiopian economy. Part II.IGAD Livestock Policy Initiative, IGAD LPI. Working Paper No. 02-11. Djibouti: IGAD.

Benin, S., Ehui, S., Pender, J. (2003). Policies for livestock development in the Ethiopian highlands. Environment, Development and Sustainability 5(3), pp. 491-510.

Benin, S., Ehui, S., Pender, J. (2006). Policies for Livestock Development in the Ethiopian Highlands. Chapter 6 in International Food Policy Research Institute (ed.), Strategies for Sustainable Land Management in the East African Highlands, Nairobi. IFPRI, pp. 141-165.

Bishu, K. G. (2014). Risk management and the potential of cattle insurance in Tigray, Northern Ethiopia. Ph.D. Thesis, University College Cork.

Blundell, R., Costa Dias, M. (2000). Evaluation methods for non-experimental data. Fiscal studies, 21(4), pp. 427-468.

Cary, J., Webb, T., Barr, N. (2001). The adoption of sustainable practices: Some new insights. An analysis of drivers and constraints for the adoption of sustainable practices derived from research. Bureau of Rural Sciences, Canberra.

Cecchi, G., Wint, W., Shaw, A., Marletta, A., Mattioli, R., Robinson, T. (2010). Geographic distribution and environmental characterization of livestock production systems in Eastern Africa. Agriculture, ecosystems \& environment 135(1), pp. 98-110.

CSA(Central Statistics Authority). (2008). Central Statistics Authority of the Federal Democratic. The Republic of Ethiopia. Agricultural sample survey 2007/2008. Vol. II. Report on livestock and livestock characteristics. Statistical bulletin. CSA: Addis Ababa, Ethiopia.

De Cao, E., van den Berg, M.M., Tile, C.Y., Wondwosen, T. (2013). The effects of zero grazing in Ethiopia. In: Proceedings of the CSAE Conference 2013: Economic Development in Africa, pp. 1-15.

del Corral, J., Perez, J.A., Roibás, D. (2011). The impact of land fragmentation on milk production. Journal of Dairy Science 94(1), pp. 517-525.

Deressa, T.T., Hassan, R.M., Ringler, C., Alemu, T., Yesuf, M. (2009). Determinants of farmers' choice of adaptation methods to climate change in the Nile Basin of Ethiopia. Global environmental change 19(2), pp. 248-255.

D’Emden, F.H., Llewellyn, R.S., Burton, M.P. (2006). Adoption of conservation tillage in Australian cropping regions: an application of duration analysis. Technological Forecasting and Social Change 73(6), pp. 630-647. 
Diao, X., Pratt, A.N. (2007). Growth options and poverty reduction in Ethiopia - An economy-wide model analysis. Food Policy 32(2), pp. 205-228.

Di Falco, S., Veronesi, M. (2013). How can african agriculture adapt to climate change?: a counterfactual analysis from Ethiopia. Land Economics 89(4), pp. 743-766.

Ehui, S., Benin, S., Paulos, Z. (2003). Policy options for improving market participation and sales of smallholder livestock producers: A case study of Ethiopia. International Conference on African Development Archives.

Ewnetu, Z., Bliss, J.C. (2010). Tree growing by small holder farmers in the Ethiopian Highlands. In: Small scale forestry in changing world: Opportunities and challenges and the role of extension and technology transfer. IUFRO conference.3.08 Small ScaleForestry, 6.06.02 Extenstion, 6.06 .01 (vol. 3).

FAO (Food and Agriculture Organization of the United Nations). (2005). Production yearbook. Rome, Italy.

FAO (Food and Agriculture Organization of the United Nations). (2007). TerrAfrica - A Vision paper for Sustainable Land Management in Sub-Saharan Africa. Food and Agriculture Organisation of the United Nations, Rome, Italy.

FAO (Food and Agriculture Organization of the United Nations). (2009). Production yearbook. Rome, Italy. Retrieved from: http://faostat.fao.org/default.aspx.

Fernandez-Cornejo, J., Hendricks, C., Mishra, A. (2005). Technology adoption and off-farm household income: the case of herbicide-tolerant soybeans. Journal of Agricultural and Applied Economics 37(3), pp. 549-563.

Frankl, A., Deckers, J., Moulaert, L., van Damme, A., Haile, M., Poesen, J., Nyssen, J. (2016). Integrated solutions for combating gully erosion in areas prone to soil piping: innovations from the drylands of Northern Ethiopia. Land Degradation \& Development 27(8), pp. 1797-1804.

Garcia, O., Balikowa, D., Kiconco, D., Ndambi, A., Hemme, T. (2008). Milk Production in Uganda. Dairy Farming Economics and Development Policy Impacts. IGAD LPI, Working Paper No. 09-08.

Gebremedhin, B., Hirpa, A., Berhe, K. (2009). Feed marketing in Ethiopia: results of rapid market appraisal. Improving Productivity and Marketing Success (IPMS) of Ethiopian farmers project working paper 15. ILRI, Nairobi.

Gebremedhin, B., Pender, J., Tesfay, G. (2004). Collective action for grazing land management in crop-livestock mixed systems in the highlands of northern Ethiopia. Agricultural Systems 82(3), pp. 273-290.

Gebreyohannes, G., Hailemariam, G. (2011). Challenges, Opportunities and Available Good Practices related to Zero Grazing in Tigray and Hararghe, Ethiopia. DCG Report No. 66.

Gessesse, B., Bewket, W., Bräuning, A. (2016). Determinants of farmers' tree-planting investment decisions as a degraded landscape management strategy in the central highlands of Ethiopia. Solid Earth, 7(2), pp. 639-650.

Ghadim, A.K.A., Pannell, D.J., Burton, M.P. (2005). Risk, uncertainty, and learning in adoption of a crop innovation. Agricultural economics 33(1), pp. 1-9.

Grassi, J., Lamberg, J., Huyer, S. (2015). Running out of time: The reduction of women's work burden in agricultural production. Food and Agriculture Organisation of the United Nations. Rome, Italy.

Gunte, K.E. (2015). Understanding factors affecting technology adoption in smallholder livestock production systems in Ethiopia: the role of farm resources and the enabling environment. Doctoral dissertation, Wageningen: Wageningen University 
Halderman, M.N. (2004). The political economy of pro-poor livestock policy making in Ethiopia. FAO working paper No. 19. Rome: FAO.

Hausman, J.A. (1978). Specification tests in econometrics. Econometrica, 46, pp. 1251-1272.

Heckman, J. (1979). Sample selection as a specification error. Econometrica, 47, pp. 153-161.

Heckman, J.J. (2001). Econometrics and empirical economics. Journal of Econometrics 100(1), pp. 3-5.

Herrero, M., Grace, D., Njuki, J., Johnson, N., Enahoro, D., Silvestri, S., Rufino, M.C. (2013). The roles of livestock in developing countries. Animal 7(1), pp. 3-18.

Holden, S.T., Westberg, N.B. (2016). Exploring technology uses under climate risk and shocks through an experimental lens. African Journal of Agricultural and Resource Economics 11(1), pp. 47-62.

Holtland, G. (2007). Eroded Consensus: however-changing policy narratives distort the interpretation of livelihood systems: the uneasy relationship between science and development, a case study from central Tanzania. The Netherlands: NUFFIC and CIDIN. Radboud University.

Huffman, W.E. (1991). Agricultural household models: survey and critique. Multiple job-holding among farm families. Hallberg, M.C., Findeis, J.L., Lass, D.A. (ed.). Ames: Iowa State University Press, pp. 79-111.

IFAD (2007). Livestock and range lands; livestock feeding. Retrieved from: http://www.ifad. org/lrkm/theme/production/feeding.htm.

Ilyin, S. (2011). The Looming Threat of Overgrazing: Effects and Recommendations. Congressional Hunger Center. Retrieved from: http://Hungercenter.wpengine.netdna-cdn.com/wp-content_Looming-Threat-of-Overgrazing-Ilyin.pdf (access date: 09.2011).

Kabirizi, J.M.L. (2006). Effect of integrating forage legumes in smallholder dairy farming systems on feed availability and animal performance. Unpublished $\mathrm{Ph} . \mathrm{D}$ thesis, Makerere University, Uganda.

Khonje, M., Manda, J., Alene, A.D., Kassie, M. (2015). Analysis of adoption and impacts of improved maize varieties in eastern Zambia. World Development 66, pp. 695-706.

Klitzing, A., Das, A., Bonzi, M., Barro A., Langkamp, U., Dereje, K., Pale, S., Nayak, S., Gupta, A. (2014). Promoting Best Practice in Agriculture: Examples from Burkina Faso, Ethiopia, India and Europe. Deutsche Welthungerhilfe e.V., Friedrich-Ebert-Straße 1, 53173 Bonn.

Kuma, B., Baker, D., Getnet, K., Kassa, B. (2014). Factors affecting market participation and volume of supply in Ethiopia. Asian Journal of Rural Development 4(1), pp. 1-15.

Lenaerts, L. (2013). Insights into Agency and Social Interactions in Natural Resource Management. Ph.D. Thesis, Wageningen University.

Lokshin, M., Sajaia, Z. (2004). Maximum likelihood estimation of endogenous switching regression models. Stata Journal, 4, pp. 282-289.

Makoni, N., Mwai, R., Redda, T., van der Zijpp, A.J., van der Lee, J. (2014). White gold: Opportunities for dairy sector development collaboration in East Africa. Centre for Development Innovation, Wageningen UR.

Meul, M., van Passel, S., Fremaut, D., Haesaert, G. (2012). Higher sustainability performance of intensive grazing versus zero-grazing dairy systems. Agronomy for Sustainable Development 32(3), pp. 629-638.

MoA (Ministry of Agriculture). (2012). Livestock growth strategy and action. Draft discussion paper. Addis Ababa: MoA. (Amharic version). 
Muuz, H. (2017). Exploring farmers' seasonal and full year adoption of stall feeding of livestock in Tigrai Region, Ethiopia. Economics of Agriculture 64(3), pp. 919-944.

Nalunkuuma, J., Affognon, H., Kingori, S.W., Salifu, D., Njonge, F.K. (2013). Adoption of zero grazing and impact on livestock keepers' knowledge of cattle reproductive parameters in Western Kenya. In: African Crop Science Conference Proceedings (vol. 11, pp. 599-604).

Nedessa, B., Ali, J., Nyborg, I. (2005). Exploring ecological and socio-economic issues for the improvement of area enclosure management. A case study from Ethiopia. Drylands Coordination Group, DCG Report No. 38.

Negassa, A., Jabbar, M. (2008). Livestock Ownership, Commercial Off-take Rates and Their Determinants in Ethiopia. Research Report 9. Nairobi, Kenya: ILRI.

Nicholson, C.F., Thornton, P.K., Muinga, R.W. (2004). Household-evel Impacts of Dairy Cow Ownership in Coastal Kenya. Journal of Agricultural Economics 55(2), pp. 175-195.

Nyssen, J., Descheemaeker, K., Nigussie Haregeweyn, M.H., Deckers, J., Poesen, J. (2007). Lessons learned from 10 years research on soil erosion and soil and water conservation in Tigray. Tigray Livelihood Papers, No. 7, Mekelle.

Odame, H., Kimenye, L., Kabutha, C., Alemu, D., Oduori, L.H. (2013). Why the low adoption of agricultural technologies in Eastern and Central Africa?. ASARECA (Association for Strengthening Agricultural Research in Eastern and Central Africa), Entebbe.

Oni, O., Fashogbon, A. (2012). Rural household consumption of milk and products in Nigeria. Journal of Agricultural and Biological Science 7(12), pp. 1062-1069.

Shiferaw, B., Kassie, M., Jaleta, M., Yirga, C. (2014). Adoption of improved wheat varieties and impacts on household food security in Ethiopia. Food Policy, 44, pp. 272-284.

Singh, I., Squire, L., Strauss, J. (1986). Agricultural Household Models. Extension, Applications, and Policy. The Johns Hopkins University Press Baltimore, Maryland 21211, USA.

Sserunkuuma, D. (2005). The adoption and impact of improved maize and land management technologies in Uganda. Journal of agricultural and development economics 2(1), pp. 67-84.

Staal, S.J., Waithaka, M., Njoroge, L., Mwangi, D.M., Njubi, D., Wokabi, A. (2003). Costs of milk production in Kenya: Estimates from Kiambu, Nakuru and Nyandarua districts. SDP Research and Development, Report No.1. Smallholder Dairy Project.

Tegebu, F.N., Mathijs, E., Deckers, J., Haile, M., Nyssen, J., Tollens, E. (2012). Rural livestock asset portfolio in northern Ethiopia: a microeconomic analysis of choice and accumulation. Tropical animal health and production 44(1), pp. 133-144.

Tegegne, A., Gebremedhin, B., Hoekstra, D., Belay, B., Mekasha, Y. (2013). Smallholder dairy production and marketing systems in Ethiopia: IPMS experiences and opportunities for market-oriented development. IPMS Working Paper 31. ILRI, Nairobi, Kenya.

Teshome, A., Graaff, J., Ritsema, C., Kassie, M. (2016). Farmers' perceptions about the influence of land quality, land fragmentation and tenure systems on sustainable land management in the north western Ethiopian highlands. Land degradation \& development 27(4), s. 884-898.

Turinawe, A., Mugisha, J., Kabirizibi, J. (2011). Socio-economic evaluation of improved forage technologies in smallholder dairy cattle farming systems in Uganda. Journal of Agricultural Science 4(3), pp. 163.

Wambugu, S., Kirimi, L., Opiyo, J. (2011). Productivity trends and performance of dairy farming in Kenya. Tegemeo Institute of Agricultural Policy and Development.

World Bank (2008). World development report. Agriculture for development. Washington, DC.

Yilma, Z., Guernebleich, E., Sebsibe, A., Fombad, R. (2011). A review of the Ethiopian dairy sector. Addis Ababa, Ethiopia: FAO Sub Regional Office for Eastern Africa (FAO/SFE). 


\title{
WPŁYW UDOSKONALONEJ PRAKTYKI ŻYWIENIA ZWIERZĄT NA PRODUKCJĘ I SPOŻYCIE MLEKA ORAZ UCZESTNICTWO W RYNKU ŻYWCA WOŁOWEGO ORAZ PRODUKTÓW POCHODZENIA ZWIERZĘCEGO W TIGRAJ W ETIOPII
}

\begin{abstract}
Abstrakt
W niniejszym opracowaniu podjęto próbę określenia wpływu całorocznego $i$ sezonowego chowu alkierzowego na produkcję $i$ spożycie mleka $w$ gospodarstwach $i$ na uczestnictwo $w$ rynku (zwierząt i produktów pochodzenia zwierzęcego) w pólnocnej Etiopii na podstawie danych uzyskanych od 518 rolników. Ustalono, że chów alkierzowy zapewnia znaczne korzyści w zakresie określonych wskaźników wyniku. Przy użyciu modeli endogenicznej regresji przełacznikowej oszacowano różne wskaźniki wyniku zarówno dla rolników stosujacych chów alkierzowy od momentu jego zastosowania (ATT), jak i dla rolników niestosujacych chowu alkierzowego (ATU) w przypadku jego zastosowania.

Stwierdzono, że gdyby rolnicy stosujacy tę metodę chowu nie zastosowali jej, to produkcja mleka $i$ wydajność mleczna spadłaby o 21\%, natomiast w przypadku rolników niestosujących chowu alkierzowego szacuje się, że produkcja mleka i wydajność mleczna wzrostyby o 100 i 48\%, gdyby go zastosowali. Wyniki pokazuja ponadto, że chów alkierzowy przyczynit się do znacznego wydtużenia okresu laktacji. Wzrost wydatków na spożycie o $17 \%$ w przypadku całorocznego $i$ 44\% w przypadku sezonowego chowu alkierzowego można uznać za znaczny $w$ odniesieniu do podstawy egzystencji drobnych producentów rolnych. Co więcej stosowanie chowu alkierzowego zwiększyło prawdopodobieństwo uczestnictwa w rynku sprzedaży zwierząt o $29 \%$ w przypadku rolników stosujacych ten rodzaj chowu i o 47\% w przypadku rolników niestosujacych go, gdyby zdecydowali się na jego zastosowanie.
\end{abstract}

Słowa kluczowe: dobrobyt gospodarstw domowych, wykorzystanie nakładów, uczestnictwo w rynku zwierząt, inwestycje gruntowe, endogeniczna regresja przełącznikowa, Etiopia.

Accepted for print: 15.06.2018.

Unless stated otherwise all the materials on the website are available under the Creative Commons Attribution 4.0 International license.

Some rights reserved to the Institute of Agricultural and Food Economics - National Research Institute.

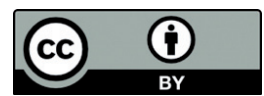

